\title{
ANALISIS GEN 16S rRNA ISOLAT SMSS-VII DAN SMSSe-VII YANG BERPOTENSI SEBAGAI BAKTERI PENDEGRADASI SOLAR
}

\section{Analised Potention of 16 S rRNA Gene SMSS VII and SMSSe VII as the Diesel Fuel Degradator Bacteria}

\author{
Rendy Leonard Huliselan, Yenni Yendri Salosa, Hermawaty Abubakar* \\ Program Studi Biologi, Fakultas Matematika dan Ilmu Pengetahuan Alam Universitas Papua \\ Manokwari 98314, Indonesia
}

*Korespondensi: hermawatyabubakar@yahoo.com

\begin{abstract}
The Objective of this research is to isolate and analisys 16s rRNA Gene which has potention as the Diesel Fuel degradator. There are 12 bacteria Isolates with SMSS medium and 5 bacteria isolates with SMSSe-VII . SMSS VII and SMSSe-VII show more colony number in SMSS dan SMSSe medium, means that those two isolates have potention as the diesel fuel degradator, because that two isolates use carbon source as the diesel fuel in SMSS and SMSSe medium.Analisation of 16 rRNA Gene from SMSS-VII and SMSSe-VII isolates started with amplification of 16 rRNA gene by using PCR (polymerase Chain Reaction) which shows by fragmentation of DNA sheet at 1300 base pairs after electroforecies process. Sequent datas of 16S rRNA of SMSS-VII and SMSSe-VII isolates is analized with BLAST-N programme. Result shows that SMSS-VII is similar to Bacillus amyloliquefaciens ATCC 23350 (NR_118290.1.), SMSSe-VII Isolate is similar to Bacillus gaemokensisstrain BL3-6 (NR_116644.1). The Maximum identity number for each is $100 \%$.
\end{abstract}

\begin{abstract}
ABSTRAK
Penelitian ini bertujuan untuk mengisolasi dan menganalisis gen 16S rRNA bakteri yang berpotensi sebagai bakteri pendegradasi solar. Diperoleh 12 isolat bakteri, tujuh isolat diisolasi dengan menggunakan media SMSS sedangkan lima isolat dengan media SMSSe. Isolat SMSS-VII dan SMSSe-VII menunjukkan jumlah koloni yang paling banyak dijumpai pada saat diisolasi di media SMSS dan SMSSe, sehingga diasumsikan bahwa kedua isolat tersebut berpotensi untuk mendegradasi solar karena memiliki kemampuan dalam memanfaatkan sumber karbon berupa solar yang terdapat pada media SMSS dan SMSSe. Analisis gen 16 rRNA isolat SMSS-VII dan SMSSe-VII diawali dengan amplifikasi gen 16 rRNA dengan menggunakan PCR (Polymerase Chain Reaction) yang ditunjukkan dengan adanya fragmen pita DNA pada ukuran 1300 pasang basa setelah dielektroforesis. Data sekuen Gen 16S rRNA isolat SMSS-VII dan SMSSe-VII dianalisa dengan menggunakan program BLAST-N, menunjukkan hasil isolat SMSS-VII memiliki kemiripan dengan Bacillus amyloliquefaciens ATCC 23350 (NR_118290.1.), sedangkan isolat SMSSe-VII dengan Bacillus gaemokensis strain BL3-6 (NR_116644.1) dengan nilai identitas maksimumnya masing-masing 100\%.
\end{abstract}

Keywords: Bacteria, Diesel Fuel, 16S rRNA Gene

\section{PENDAHULUAN}

Bahan bakar minyak merupakan salah satu kebutuhan utama bagi setiap manusia pada saat ini. Bahan bakar minyak juga merupakan sumber energi yang banyak digunakan untuk industri, transportasi darat, transportasi laut, dan rumah tangga (Kadarwati., et al, 1996).
Bahan bakar minyak yang digunakan untuk transportasi laut pada umumnya menghasilkan tumpahan minyak sebagai limbah yang dapat mencemari perairan (Udiharto, 1996). Tumpahan minyak merupakan polutan yang dapat mengganggu ekosistem pada daerah yang telah terkontaminasi (Komarawidjaja dan 
Lysiastuti, 2009). Daerah pesisir maupun area lepas pantai sangat rentan terkontaminasi dan belakangan ini semakin meningkat dengan adanya aktivitas nelayan yang menggunakan salah satu minyak bumi yakni minyak solar dengan harga yang relativ murah sebagai bahan bakar pada transportasi laut.

Minyak solar merupakan salah satu minyak bumi yang dapat diperoleh dengan cara destilasi yang dapat dipisahkan berdasarkan titik didih $300^{\circ}-400^{\circ} \mathrm{C}$ (Pertamina, 2005). Solar termasuk dalam kategori B3 (Bahan Beracun dan Berbahaya) yang harus ditanggulangi karena tumpahannya ke perairan dapat menyebabkan kerusakan parah pada ekosistem. Limbah minyak solar juga dapat menyebabkan peningkatan penyakit serius yang berpotensi membahayakan manusia dan lingkungan. Salah satu alternatif yang dapat digunakan dalam penanggulangan pencemaran minyak bumi adalah bioremediasi (Nugroho, 2006).

Bioremediasi merupakan suatu proses pendegradasian bahan organik berbahaya secara biologis menjadi senyawa lain seperti karbondioksida $\left(\mathrm{CO}_{2}\right)$, metan, dan air (Ciroreksoko, 1996). Proses biodegradasi dikembangkan untuk mengurangi pencemaran limbah minyak yang berada di perairan. Perairan Pelabuhan Rakyat Manokwari telah tercemari limbah minyak yang diakibatkan oleh aktivitas kapal-kapal besar. Perairan laut yang telah tercemar ini dikuwatirkan akan mengganggu stabilitas dan keseimbangan lingkungan.

Pelabuhan Rakyat Manokwari merupakan pelabuhan terbesar sekaligus pelabuhan utama di Manokwari yang berada dibawah manajemen PT. PELNI. Pelabuhan Rakyat Manokwari beroperasi selama 24 jam dalam satu hari, dan berada di bagian Teluk Doreri. Dari data yang diperoleh bahwa jumlah kapal yang beroperasi di Pelabuhan Rakyat Manokwari yaitu \pm 35 kapal/bulan, sehingga tingginya densitas trafik di Pelabuhan Rakyat Manokwari menimbulkan konsekuensi baru yaitu kecenderungan meningkatnya volume buangan kapal khususnya pada tumpahan minyak yang secara langsung menjadi limbah dan mencemari pesisir pantai pelabuhan rakyat Manokwari tersebut.

Upaya penanggulangan pencemaran minyak pada perairan laut dapat dilakukan melalui berbagai proses yaitu proses fisika, kimiawi dan biologis (mikroba). Proses biologis dianggap paling baik dilakukan untuk upaya penanggulangan pencemaran karena akan terjadi proses biodegradasi minyak oleh mikroba. Selain itu, bakteri pendegradasi minyak berkembang lebih lambat, sehingga perlu dilakukan isolasi bertahap untuk mendapatkan isolat bakteri yang mampu mendegradasi solar lebih lengkap.

\section{METODE}

\section{Bahan Penelitian}

Bahan yang digunakan adalah Stone Mineral Salt Solution (SMSS) dan Stone Mineral Salt Solution extract yeast (SMSSe), minyak solar, air laut, akuades, alkohol 70\%, primer 63f (5'-CAGGCCTAACACATGCA AGTC-3') dan primer 1387r (5'GGGCGGWGTGTACAAGG C-3'), mini Kit DNA Extraction (Qiagen), Larutan EDTA, Go Taq Green (Promega), dd $\mathrm{d}_{2} \mathrm{O}$, gel agarose, dan Marker DNA ladder $1 \mathrm{~Kb}$.

\section{Pengambilan Sampel}

1. Sampel diambil dengan botol kaca bening yang dilengkapi dengan penutup dan diberi label pada salah satu sisi botol.

2. Sterilisasi alat dan bahan sebelum digunakan, dengan menggunakan autoclave pada suhu $121^{\circ} \mathrm{C}$ dengan tekanan 1 atm selama $15-30$ menit. Sebelum disterilkan, botol dibungkus seluruhnya dengan kertas.

3. Pengambilan sampel dilakukan dengan membuka bungkus kertas dan botol dipegang di bagian bawah yang masih ada kertas bungkusnya sehingga tangan tidak bersentuhan dengan mulut botol.

4. Pengambilan sampel diambil pada tiga titik yaitu titik pertama diambil pada bagian pesisir, titik kedua diambil dengan jarak 5 meter ke bagian laut dari titik pertama, titik ketiga diambil dengan jarak 5 meter ke bagian laut dari titik kedua, untuk jarak sisi kiri dan kanan masing-masing 10 meter.

5. Sampel diambil pada permukaan air laut dengan mensejajarkan mulut botol dengan permukaan air laut.

6. Kemudian botol sampel yang telah berisi air laut yang terkontaminasi limbah minyak selanjutnya dikomposit. Dimasukkan dalam coolbox dan dibawa ke Laboratorium 
Mikrobiologi Jurusan Biologi FMIPA UNIPA.

7. Selanjutnya sampel air laut yang terkontaminasi minyak dikompositkan dan dilakukan analisis lebih lanjut.

Isolasi dan Pemurnian Bakteri Pendegradasi Minyak Solar

Medium basal yang digunakan terdiri dari Stone Mineral Salt Solutiont (SMSS) yang dilarutkan dalam $200 \mathrm{ml}$ air laut (Sharpley, 1996). Ekstraksi ragi sebanyak $0.01 \%$ (b/v) ditambahkan ke dalam medium SMSS, sehingga menjadi media SMSSe (SMSS mengandung ekstrak ragi). Selanjutnya media SMSSe ditambahkan minyak solar sebanyak $2 \%(\mathrm{~b} / \mathrm{v})$, dan $\mathrm{pH}$ medium ini adalah 6.8-7.

\section{Isolasi Tahap I}

1. Sampel air laut yang terkena tumpahan minyak sebanyak $2 \%(\mathrm{~b} / \mathrm{v})$ dimasukkan ke dalam media SMSS yang mengandung minyak solar $2 \%$ (b/v) diinkubasi selama 7 hari pada suhu ruang dengan digoyang di atas shaker pada kecepatan $120 \mathrm{rpm}$.

2. Pada proses isolasi sampel diambil pada hari ke-1, 3, 5 dan 7.

3. Isolasi dilakukan dengan metode pengenceran dengan menggunakan pengenceran $10^{-5}$ dengan air laut steril.

4. Isolat diambil sebanyak $1 \mathrm{ml}$ untuk dibiakkan di atas lempeng agar SMSS yang mengandung solar $2 \%(\mathrm{~b} / \mathrm{v})$ dan $2 \%$ bacto agar sebagai pemadat dengan metode cawan sebar dengan menggunakan spreader lalu diinkubasi pada suhu $35^{\circ} \mathrm{C}$ selama 2 hari.

5. Setiap koloni yang berbeda dimurnikan kembali pada medium padat yang serupa.

\section{Isolasi Tahap II}

1. Isolasi tahap II dilakukan dengan tetap menggunakan sampel air laut yang terkena tumpahan minyak dan dilakukan dengan prosedur dan kondisi yang sama, tetapi medium pengisolasinya (SMSSe) diperkaya dengan minyak sisa degradasi (MSD). MSD adalah minyak sisa degaradasi yang diperoleh dari tahap I dengan cara mendinginkan media tahap I di dalam kulkas pada suhu $5^{\circ} \mathrm{C}$ selama \pm 15 menit, kemudian lapisan minyak pada bagian atas media diambil dengan Spatula.

2. Kultur diinkubasi selama 7 hari pada suhu ruang dengan digoyang di atas shaker pada kecepatan $120 \mathrm{rpm}$.

3. Pada proses isolasi sampel diambil pada hari ke-1, 3, 5 dan 7.

4. Isolasi dilakukan dengan metode pengenceran dengan menggunakan pengenceran $10^{-5}$ dengan air laut steril.

5. Isolat diambil sebanyak $1 \mathrm{ml}$ untuk dibiakkan di atas lempeng agar SMSSe yang mengandung solar $2 \%(\mathrm{~b} / \mathrm{v})$ dan $2 \%(\mathrm{~b} / \mathrm{v})$ bacto agar sebagai pemadat dengan metode cawan sebar dengan menggunakan spreader lalu diinkubasi pada suhu $35^{\circ} \mathrm{C}$ selama 2 hari.

6. Setiap koloni yang berbeda dimurnikan kembali pada medium padat yang serupa.

\section{Karakterisasi Morfologi Sel dan Tipe Dinding Sel (Pewarnaan Gram)}

Karakterisasi morfologi atau pewarnaa Gram bertujuan untuk melihat bentuk morfologi dan sifat pewarnaan dari mikroorganisme. Morfologi koloni dapat diamati di bawah mikroskop.

Metode pengecatan Gram merujuk pada Capuccino dan Sherman (2014) sebagai berikut:

1. Menyiapkan kaca objek yang bersih.

2. Mengambil kultur bakteri secara aseptic dan dioleskan pada kaca objek dengan menggunakan ose bulat dan diberi satu tetes air steril untuk membantu menyebarkan bakteri secara merata pada kaca objek.

3. Olesan bakteri kemudian difiksasi di atas lampu Bunsen.

4. Selanjutnya ditetesi Gram A (kristal violet) sebanyak 2-3 tetes di atas olesan bakteri sampai semua olesan terendam, lalu dibiarkan selama 1 menit.

5. Olesan kemudian dicuci dengan air mengalir.

6. Diatas olesan bakteri ditambahkan Gram B (larutan iodin) sebanyak 2-3 tetes dan dibiarkan terendam selama 1 menit dan dicuci dengan air mengalir.

7. Setelah itu olesan bakteri ditetesi dengan Gram C (alkohol) sebanyak 2-3 tetes, dibiarkan selama 15 detik. Olesan bakteri dicuci kembali dengan air mengalir.

8. Teteskan Gram D (larutan safranin) sebanyak 2-3 tetes selama 1 menit dan dicuci 
kembali dengan air mengalir lalu dikeringkan.

9. Preparat diamati di bawah mikroskop. Jika penampakan sel bakteri berwarna ungu bakteri bersifat Gram positif, tetapi jika berwarna merah maka bakteri bersifat Gram negatif.

\section{Analisis Gen 16S rRNA}

Ekstraksi DNA Isolat mengikuti prosedur Protocol Mini Kit DNA Extraction (Qiagen)

1. Koloni bakteri diambil sebanyak $1,5 \mathrm{ml}$ dan dimasukkan ke dalam ependorf, kemudian disentrifugasi dengan kecepatan 16000 rpm selama 10 menit lalu supernatan dibuang.

2. Larutan GT buffer sebanyak $200 \mu$ l ditambahkan ke dalam pellet lalu divortex sampai homogen.

3. Ditambahkan $10 \mu \mathrm{l}$ Proteinase K selanjutnya divortex dan diinkubasikan pada suhu $60^{\circ} \mathrm{C}$ selama 30 menit.

4. Ditambahkan $200 \mu \mathrm{l}$ GBT buffer, divortex selam 5-10 detik dan diinkubasi pada suhu $60^{\circ} \mathrm{C}$ selama 20 menit.

5. Ditambahkan $200 \mu$ absolute ethanol, selanjutnya divortex selam 10 detik.

6. Selanjutnya kolom GD disiapkan, ditempatkan pada tabung koleksi $2 \mathrm{ml}$, campuran (termasuk gumpalan DNA) dipindahkan pada kolom GD, dan disentrifugasi pada kecepatan $15.000 \mathrm{rpm}$ selama 2 menit.

7. Kemudian, kolom GD dipindahkan pada tabung koleksi $2 \mathrm{ml}$ yang baru, $400 \mu \mathrm{lW} 1$ buffer ditambahkan pada kolom GD, dan disentrifugasi pada kecepatan $15.000 \mathrm{rpm}$ selama 30 detik untuk mendapatkan DNA yang murni.

8. Filtrat dibuang dan kolom GD dikembalikan ke tabung koleksi $2 \mathrm{~mL}$. Setelah itu, $600 \mu \mathrm{l}$ wash buffer ditambahkan pada kolom GD dan disentrifugasi pada kecepatan $15.000 \mathrm{rpm}$ selama 30 detik.

9. Filtrat dibuang dan kolom GD dikembalikan ke tabung koleksi $2 \mathrm{~mL}$ dan disentrifugasi selama 3 menit. Kolom GD dimasukkan ke dalam tabung 1,5 ml yang baru, setelah itu, $100 \mu$ l elution buffer (yang telah dipanaskan pada suhu $60^{\circ} \mathrm{C}$ ) ditambahkan pada kolom GD, tunggu selama 5 menit pada suhu kamar untuk memastikan elution buffer terserap sepenuhnya, dan campuran disentrifugasi pada kecepatan 15.000 rpm selama 30 detik.

10. Selanjutnya hasil ekstraksi tersebut disimpan dalam freezer.

\section{Amplifikasi Gen 16S rRNA dengan PCR (Polymerase Chein Reaction)}

1. Amplifikasi gen $16 \mathrm{~S}$ rRNA menggunakan PCR (Thermal Cycler) tipe MJ mini Biorad model TN 1148 dengan primer 63f (5'CAGGCCTAACACATGCAAGTC-3') dan 1387r(5'-GGGCGGWGTGTACAAGGC-3') yang akan memperbanyak fragmen pada target sekitar $1300 \mathrm{pb}$. (Marchesi et al., 1998).

2. Total volume reaksi yang digunakan adalah

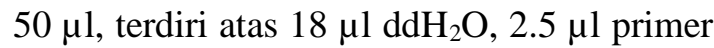
63f, $2.5 \mu \mathrm{l}$ primer $1387 \mathrm{r}, 25 \mu \mathrm{l}$ Go Taq Green (Promega), $2 \mu \mathrm{l}$ Ekstrak DNA.

3. Profil suhu PCR yang digunakan adalah denaturasi awal pada suhu $94^{\circ} \mathrm{C}$ selama 3 menit, diikuti dengan 35 siklus yang terdiri dari 3 tahap yaitu denaturasi pada suhu $94^{\circ} \mathrm{C}$ selama 30 detik, anneling pada suhu $50^{\circ} \mathrm{C}$ selama 30 detik, dan extention pada suhu $72^{\circ} \mathrm{C}$ selama 45 detik, tahap akhir yaitu final extention pada suhu $72^{\circ} \mathrm{C}$ selama 7 menit.

\section{Elektroforesis Gel Agarosa}

Hasil ekstrak DNA dan produk dari PCR divisualisasikan menggunakan Elektroforesis Gel Agarosa, untuk mengetahui keberhasilan dari proses isolasi DNA dan PCR. Metode yang dilakukan mengikuti Puspaningrum (2005) sebagai berikut:

1. Agarosa 0.4 gr dimasukkan dalam gelas piala, selanjutnya ditambahkan $40 \mathrm{ml}$ buffer SB (sodium borix) dan panaskan dalam microwave hingga semua agarosa terlarut dan berwarna bening.

2. Selanjutnya larutan agarosa dituang ke dalam cetakan gel dan diamati jangan sampai ada gelembung, selanjutnya didiamkan hingga mengeras sekitar 20 menit.

3. Pada proses elektroforesis, gel yang sudah mengeras dimasukkan ke dalam tangki elektroforesis yang berisi SB buffer dan hamparkan parafilm.

4. $4 \mu \mathrm{l}$ loading dye diambil dan totolkan pada parafilm menjadi 4 totol, selanjutnya $4 \mu \mathrm{l}$ ekstrak DNA dan produk PCR diambil dan 
dicampurkan dengan salah satu totolan loading dye hingga merata.

5. Selanjutnya campuran tersebut diambil dan dimasukkan ke dalam sumur gel (pada sumur kedua), sedangkan DNA marker dimasukkan ke sumur pertama.

6. Running mesin pada tegangan 100 volt selama 30 menit.

7. Setelah 30 menit, gel tersebut diangkat dan dimasukkan ke dalam larutan EtBr (Etidium Bromide) dan diamkan selama 15 menit, kemudian gel dibilas dengan air dan didiamkan beberapa saat.

8. Gel divisualisasikan dengan menggunakan UV transluminator dan didokumentasikan menggunakan kamera digital.

\section{Sekuensing Gen 16S rRNA}

Sekuensing DNA dilakukan dengan menggunakan metode dideoksiterminasi Sanger, dengan menggunakan jasa layanan sekuensing dari PT. Genetika Science, Jakarta. Selanjutnya hasil sekuensing berupa eletroferogram dalam format $\mathrm{AB} 1$ file dikirim via email.

\section{Analisis Data}

Analisis data dilakukan dengan pengamatan secara kualitatif dan disajikan dengan gambar dan tabel. Sekuens DNA disejajarkan dengan menggunakan software MEGA 5.1 dan dibandingkan dengan menggunakan BLAST pada data GenBank NCBI.

\section{HASIL DAN PEMBAHASAN}

\section{Isolasi dan Seleksi Bakteri Pendgradasi Minyak Solar}

Isolasi tahap pertama pada media SMSS diperoleh tujuh isolat yaitu SMSS-I1, SMSS-I2, SMSS-III1, SMSS-III2, SMSS-V1, SMSS-V2, dan SMSS-VII. Pada isolasi tahap kedua diperoleh lima isolat yaitu SMSSe-I1, SMSSeI2, SMSSe-III, SMSSe-V, dan SMSSe-VII, sehingga diperoleh 12 isolat bakteri yang berpotensi sebagai pendegradasi minyak solar. Isolat-isolat bakteri pendegradasi minyak solar dibedakan berdasarkan pengamatan warna, bentuk, tepi dan elevasi koloni (Tabel 1). Perbedaan morfologi ini merupakan karakteristik awal yang membedakan antara jenis bakteri. Karakterisasi morfologi koloni dan warna perlu dilakukan agar mempermudah dalam proses identifikasi jenis bakteri. Hal ini sesuai dengan pernyataan Lay (1994), bahwa berdasarkan ciri morfologi koloni, bakteri dapat diidentifikasi, namun untuk memperoleh hasil identifikasi yang sempurna maka harus dilanjutkan dengan uji biokimia dan molekuler.

Pengamatan sampel pada media SMSS dan SMSSe pada masa inkubasi menunjukkan adanya perubahan warna pada media yang diberi sampel air laut dan solar. Media yang diberi sampel air laut dan solar lama-kelamaan menjadi keruh setelah di shaker. Kekeruhan pada media kultur menujukkan adanya pertumbuhan bakteri. Pertumbuhan bakteri pada medium yang mengandung solar (SMSS) menunjukkan bahwa isolat bakteri yang diperoleh mampu menggunakan solar sebagai sumber karbon organik selain yeast ekstrak. Menurut Sitti Hamdiyah (2000) media kultur akan terlihat lebih keruh. Setelah 3 hari pengamatan secara visual, mulai terlihat warna media yang berubah menjadi lebih keruh. Kondisi minyak mentah dalam media juga bervariasi sejak hari ke 3, sehingga bakteri yang dihasilkan pun akan bervariasi, karena kemampuan mikroorganisme dalam mendegradasi hidrokarbon.

Pada isolasi tahap kedua yang menggunakan media SMSS yang ditambahkan dengan yeast ekstrak (SMSSe) dan MSD (minyak sisa degradasi). Penambahan yeast ekstrak bertujuan untuk menambahkan sumber karbon bagi bakteri yang tumbuh pada media kultur, sedangkan MSD bertujuan untuk membantu proses penguraian bakteri sehingga diperoleh jenis-jenis bakteri baru yang berbeda dari hasil isolasi tahap pertama.

Dua isolat yang paling banyak dijumpai pada saat proses isolasi adalah isolat SMSS-VII dan SMSSe-VII. Koloni isolat SMSS-VII dan SMSSe-VII memiliki kehadiran yang paling sering dan banyak, hal ini mengindikasikan tingkat pertumbuhan kedua isolat tersebut lebih baik pada media kultur SMSS dan SMSSe. Kemampuan isolat bakteri mendegradasikan minyak solar juga disebabkan karena bakteri menghasilkan enzim yang mampu memecah senyawa organik kompleks menjadi senyawa yang lebih sederhana. Enzim monooksigenase dan enzim dioksigenase yang dihasilkan oleh 
bakteri mampu membuka ikatan karbon pada cincin aromatik dan menghasilkan alkohol primer. Dengan menggunakan dua molekul oksigen, enzim dioksigenase yang dihasilkan oleh bakteri mendegradasi PAH dan membentuk cis-dihidrodiol. Senyawa ini kemudian didehidrogenasi untuk membentuk dihidroksiPAH yang merupakan substrat untuk enzim membuka cincin. Melalui pemberian satu molekul oksigen maka enzim monooksigenase juga dapat mendegradasi PAH dan membentuk arene oksida, dengan penambahan ion $\mathrm{H}^{+}$dan $\mathrm{OH}^{-}$maka enzim hidrolase mengkatalisis arene oksida membentuk trans-dihidrodiol, selanjutnya molekul-molekul ini akan digunakan oleh mikroba sebagai sumber nutrisi untuk pertumbuhan dan energi (Munir, 2006).

\section{Pewarnaan Gram}

Berdasarkan uji pewarnaan gram pada isolat SMSS-VII dan SMSSe-VII menunjukkan bahwa bakteri yang diperoleh merupakan bakteri gram positif karena hasil pengecetan berwarna ungu. Hal ini disebabkan karena bakteri mampu mempertahankan zat warna kristal violet sewaktu proses pewarnaan gram. Gram positif akan memberikan warna ungu kebiruan. Menurut Brown (2001), pada Gram negatif akan memberikan warna merah karena lipid yang terdapat dalam dinding selnya akan larut pada waktu pencucian dengan alkohol. Sehingga pori-pori dan dinding sel akan membesar dan menyebabkan terlepasnya kompleks kristal violet yang diserap sebelumnya sehingga bakteri akan berwarna merah setelah diberikan safranin.

Tabel 1. Karakterisasi koloni dan tipe dinding sel isolat bakteri pendegradasi minyak solar hasil isolasi tahap I dan II

\begin{tabular}{|c|c|c|c|c|c|c|}
\hline No & Isolat & $\begin{array}{l}\text { Bentuk } \\
\text { Koloni }\end{array}$ & $\begin{array}{c}\text { Tepi } \\
\text { Koloni }\end{array}$ & $\begin{array}{l}\text { Elevasi } \\
\text { Koloni }\end{array}$ & $\begin{array}{l}\text { Warna } \\
\text { Koloni }\end{array}$ & $\begin{array}{c}\text { Pewarnaan } \\
\text { Gram }\end{array}$ \\
\hline \multicolumn{7}{|c|}{ Isolasi tahap I } \\
\hline 1 & SMSS-I1 & Irregular & Undulate & Flat & Putih & - \\
\hline 2 & SMSS-I2 & Irregular & Undulate & Raised & Kuning & - \\
\hline 3 & SMSS-III1 & Circular & Enitire & Raised & Krem & - \\
\hline 4 & SMSS-III2 & Irregular & Undulate & Raised & Putih & - \\
\hline 5 & SMSS-V1 & Irregular & Lobate & Raised & Putih & - \\
\hline 6 & SMSS-V2 & Irregular & Undulate & Raised & Putih & - \\
\hline 7 & SMSS-VII & Irregular & Undulate & Raised & Putih & + \\
\hline \multicolumn{7}{|c|}{ Isolasi tahap II } \\
\hline 1 & SMSSe-I1 & Circular & Undulate & Raised & Krem & - \\
\hline 2 & SMSSe-I2 & Circular & Enitire & Flat & Krem & - \\
\hline 3 & SMSSe-III & Circular & Undulate & Flat & Krem & - \\
\hline 4 & SMSSe-V & Circular & Undulate & Flat & Krem & - \\
\hline 5 & SMSSe-VII & Circular & Undulate & Flat & Krem & + \\
\hline
\end{tabular}

\section{Ekstraksi Genom DNA Bakteri}

Berdasarkan hasil elektroforesis pada tegangan 100 volt selama 30 menit dengan gel agarosa $1 \%$ tampak pita genom bakteri yang memiliki ukuran relativ seragam $(\approx 10,000 \mathrm{pb})$ (Gambar 1) pada kedua isolat (SMSS-VII dan SMSSe-VII) yang divisualisasikan menggunakan UV transmilator.

Proses ekstraksi pada dasarnya terdiri dari beberapa tahapan besar yaitu homogenization (homogenisasi), CellLysis (pelisisan membran),
DNA Binding (DNA pengikat), wash (pencuci), dan DNA elution. Proses homogenisasi diawali dengan pemberian larutan GT Buffer yang berperan dalam proses homogenisasi sel. Selanjutnya ditambahkan GBT Buffer yang berperan penting dalam pelisisan membran sel bakteri sehingga materi DNA genom bakteri dapat keluar dari dalam sel. Proses lisis ditandai dengan adanya lendir berwarna putih transparan (pelet atau endapan) yang terletak dibagian dasar tabung ekstraksi. 


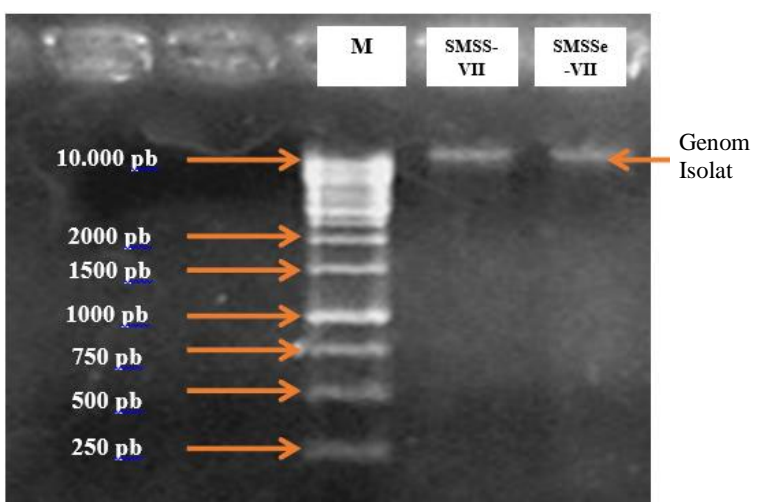

Gambar 1. Hasil Ekstraksi Genom DNA Isolat Bakteri SMSS-VII dan SMSSe-VII

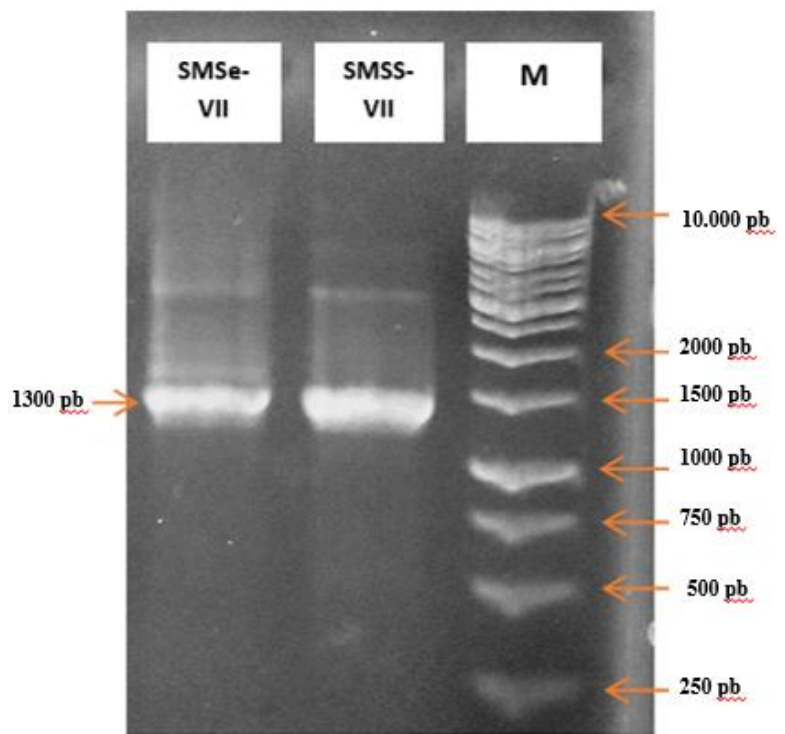

Gambar2. Hasil amplifikasi fragmen pita DNA bakteri pada gel agarosa $1 \%$

Amplifikasi Gen 16S rRNA dengan PCR (Polymerase Chein Reaction)

Hasil PCR yang berupa amplikon atau kopian gen 16S rRNA, selanjutnnya dielektroforesis untuk mengetahui keberhasilan dari proses amplifikasi gen 16S rRNA dengan menggunakan Primer 63f dan 1387r. Panjang pita DNA yang teramplifikasi pada pada isolat SMSSVII dan SMSSe-VII memiliki ukuran yang sama yaitu $\approx 1,300 \mathrm{pb}$ (Gambar 2.).

Isolat SMSS-VII memiliki kemiripin terdekat dengan Bacillus amyloliquefaciens ATCC 23350 merupakan bakteri yang diperoleh dengan Bacillus amyloliquefaciens yang terisolasi dari kepiting asin (poo-khem) di Thailand. Isolat SMSSe-VII memiliki kemiripan dengan Bacillus gaemokensis strain BL3-6 dan identitas maksimumnya $99 \%$ dengan N0. Akses NR_116644.1 sehingga berdasarkan penelitian terdahulu bahwa gaemokensis ini diisolasi dari sedimen datar pasang surut dari laut kuning di wilayah Tae-An Korea (Jung, 2010). Bossert dan Bartha (1984) menemukan bakteri yang mendominasi pada perairan yang tercemari minyak bumi yaitu dari genera Alcaligenes, Arthrobacter, Acinetobacter, Nocardia, Achromobacter, Bacillus, Flavobacterium, dan Pseudomonas.

\section{Analisis Sekuens Gen 16S rRNA}

Analisis sekuen gen 16S rRNA menunjukkan bahwa dari kedua isolat bakteri antimikrob tersebut memiliki kemiripan yang dibandingkan berdasarkan penelitian sebelumnya dari hasil BLAST-N (Tabel 2.).

\section{Pohon filogeni berdasarkan hasil sekuensing}

Hasil kontruksi pohon filogeni berdasarkan MEGA 5.1 menghasilkan hubungan kekerabatan antara isolat-isolat reference strains yang berasal dari GenBank (www.NCBI.com). Pemilihan isolat reference strains didasarkan atas kesamaan panjang pasang basa DNA dan kesamaan habitat dengan isolat SMSS-VII dan SMSSe-VII. Berdasarkan hasil konstruksi pohon filogeni menunjukkan skala persentasi yang berbeda.

Berdasarkan kontruksi pohon filogeni digunakan beberapa galur acuan (reference strains) yang bertujuan untuk mengetahui seberapa dekat hubungan kekerabatan antara isolat SMSS-VII dan SMSSe-VII dengan reference stains berdasarkan hasil sekuensing gen 16S rRNA. Hasil pohon filogeni yang menggunakan data sekuen parsial gen 16S rRNA isolat dengan aktivitas antimikrob terbaik dan beberapa galur acuan (reference strains) menunjukkan adanya kedekatan hubungan kekerabatan yang dilihat berdasarkan habitat dan jumlah pasang basa DNA yang diperoleh. Isolat SMSS-VII memiliki hubungan kekerabatan dengan $B$. amyloliquefaciens ATCC 23350 dan B. amyloliquefaciens, sedangkan isolat SMSSe-VII memiliki hubungan kekerabatan dengan B. cereus L16 al 37, B. cereus ALA3, B. cereus AT RB31, B. cereus $\mathrm{PW} 9$ aco $37 \mathrm{~b}, \mathrm{~B}$. marcorestinctum LQQ, B.thuringiensis NBRC 101235 dan B. gaemokensis. 
Tabel 2. Analisis Homologi Sekuen Gen 16S rRNA menggunakan program BLAST-N

\begin{tabular}{|l|l|c|c|}
\hline \multicolumn{1}{|c|}{ Isolat } & \multicolumn{1}{|c|}{ Homolog } & \% Identitas & No. Akses \\
\hline SMSS-VII & $\begin{array}{l}\text { Bacillus amyloliquefaciens } \\
\text { ATCC 23350 }\end{array}$ & $98 \%$ & NR_118290.1 \\
\hline SMSSe-VII & $\begin{array}{l}\text { Bacillus gaemokensis } \\
\text { BL3-6 }\end{array}$ & $99 \%$ & NR_116644.1 \\
\hline
\end{tabular}

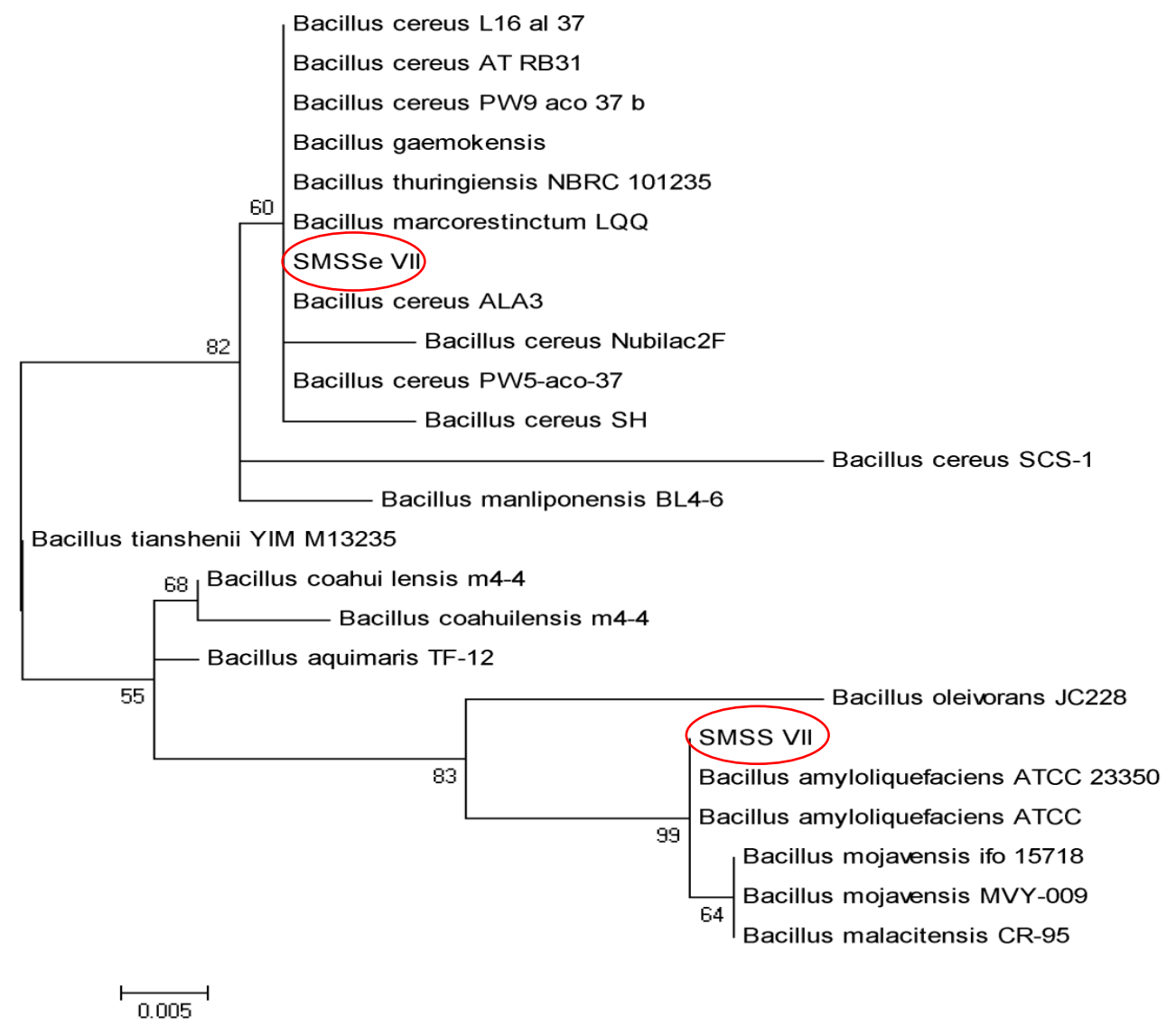

Gambar 3. Pohon filogeni berdasarkan hasil sekuensing gen 16S rRNA dan menggunakan algoritma Maximum Likelihood dengan model evolusi Tamura-Nei dan bootstrap 1000

\section{SIMPULAN}

Diperoleh 12 isolat bakteri pendegradasi minyak solar yang berbeda berdasarkan warna, bentuk, tepi dan elevasi koloni. Koloni isolat SMSS-VII dan SMSSe-VII memiliki kehadiran yang paling banyak pada masing-masing pada media SMSS dan SMSSe. Analisis sekuen gen 16S rRNA dengan BLAST-N menunjukkan Isolat SMSS-VII memiliki kemiripin terdekat dengan Bacillus amyloliquefaciens ATCC 23350 dan identitas maksimumnya 98\% dengan
No. Akses NR_118290.1. Isolat SMSSe-VII memiliki kemiripan dengan Bacillus gaemokensis BL3-6 dan identitas maksimumnya 99\% dengan N0. Akses NR_116644.1. Konstruksi pohon filogeni menggunakan MEGA 5.1 Maximum Likekihood, menunjukkan Isolat SMSS VII memiliki hubungan kekerabatan dengan B. amyloliquefaciens ATCC 23350, B. cereus AT RB31, B. marcorestinctum LQQ, B. cereus PW9 aco 37b, B. thuringiensis NBRC 101235 dan B. gaemokensis. 


\section{DAFTAR PUSTAKA}

Bairagi A, Ghosh K, Sen SK, Ray AK. 2002. Enzyme producing bacterial flora isolated from fish digestive tracts. Aquaculture International. 10:109-121.

Bossert I, Bartha R. 1984. The fate of petroleum in soil ecosystems. Didalam: Atlas RM, editor. Petroleum Microbiology. New York: Macmillan Publishing Co. hlm 435473.

Cappuccino JG, Sherman N. 2014. Microbiology: A Laboratory Manual. New York: The Benjamin Cummings Publishing Company. 9 Edicition.

Ciroreksoko P. 1996. Pengantar Bioremediasi dan Peranan Bioremediasi dalam Pengelolaan Lingkungan. Cibinong.

Duncan F. 2005. MCB 1000L Applied Microbiology Laboratory Manual. $4^{\text {th }}$ Ed. The McGraw-Hill Companies. Ney York marine sediments. Int $\mathrm{J}$ Syst Bacteriol 45:116-123.

Jawetz, Melnick, Adelberg. 1995. Mikrobiologi Kedokteran. EGC. Jakarta.

Jung, Min-Young. 2010. Bacillus gaemokensis sp. nov., isolated from foreshore tidal flat sediment from the Yellow Sea. Korea.

Kadarwati SM, Udiharto EH, Legowo E, Bagio M, Rahman E, Jasjfi. 1994. Aktivitas mikroba dalam transformasi substansi di lingkungan situs hidrokarbon. Lembaran Publikasi Lemigas 2:28-38.

Komarawidjaja W, Lysiastuti E. 2009. Status Konsorsium Mikroba Lokal Pendegradasi Minyak. Jurnal Teknologi Lingkungan. Vol. 10 No.3 Hal 347-354. ISSN 1441-318X.
Lay WB. 1994. Analisis Mikroba di Laboratorium. PT Raja Grafindo Persada, Jakarta.

Marchesi JR, Sato T, Weightman AJ, Martin TA, Fry JC, Hiom SJ, Wade WG. 1998. Design and evaluation of useful bacteriumspecific PCR primers that amplify genes coding for bacterial 16S rRNA. Appl Environ. Microbiol 64:795-9.

Nugroho A. 2006. Bioremediasi Hidrokarbon Minyak Bumi. Yogyakarta: Graha Ilmu Ch. 1-Ch. 4.

Pelczar MJ, Chan ECS. 2006. Dasar-Dasar Mikrobiologi. Volume ke-1. Hadioetomo.

RS, Imas T, Tjirosomo SS, Angka SL, penerjemah; Jakarta: UI Pr. Terjemahan dari: Elements of Microbiology.

Pertamina. 2005. Industrial Diesel Oil (Minyak Diesel). http://www.Pertamina.com/indo nesia/head-office/hilir-ppdn/product/prdsolar.html. (12 Mei 20015)

Puspaningrum A. 2008. Penerapan Metode PCR Menggunakan Primer 16E1 dan 16E1 untuk Mendeteksi Escherichia coli Dalam Berbagai Sampel Air. Skripsi Departemen Farmasi Fakultas Matematika dan Ilmu Pengetahuan Alam Universitas Indonesia. Depok.

Sharpley JM. 1996. Elementary Petroleum Microbiology, Gulf Publishing Company. Texas. 65-95, 115-117.

Udiharto M. 1996. Bioremediasi Miyak Bumi. Prosiding Pelatihan dan Lokakarya "Peranan Bioremediasi dalam Pengelolaan Lingkungan”, Cibinong 24-28 Juni 1996. LIPI-BPPT-HSF. 